\title{
Marriage is for heterosexuals - may the rest of us be saved from it
}

\author{
Kenneth McK Norrie, Professor of Law, University of Strathclyde
}

\section{Introduction}

In the great movement towards gay and lesbian equality the major battles of the past few decades ${ }^{1}-$ be it decriminalisation, ${ }^{2}$ equality in ages of consent, ${ }^{3}$ protection from discrimination ${ }^{4}$ or access to military service ${ }^{5}$ - have all concerned matters upon which there is a broad and fairly obvious consensus amongst gay men and lesbians. They have all, as well, involved individual rights. However, a new generation of disputes is emerging which concerns relationships rather than individuals, ${ }^{6}$ and, excitingly, there is no clear consensus amongst gay activists and queer theorists as to the end result that is being sought.

More and more jurisdictions are granting recognition to same-sex relationships, some on an ad hoc basis, others more comprehensively. Denmark, in 1989, innovatively introduced a whole new domestic institution for same-sex couples, known as 'registered partnerships', ${ }^{7}$ and that lead has been followed by a handful of European countries ${ }^{8}$ and by the state of Vermont in the US (where the institution is known as 'civil unions'). The Dutch Parliament has voted in favour of opening up marriage itself to same-sex couples. ${ }^{9}$ Many people would consider this a step too far. While welcoming any development that advances the cause of gay and lesbian equality, or that helps to change social attitudes towards a more tolerant and inclusive direction, I nevertheless consider the Dutch innovation a step in the wrong direction. Some activists and queer theorists take the view that opening up marriage to same-sex couples will be the ultimate recognition of both social and legal acceptability of homosexuality; ${ }^{10}$ many feminists see marriage as a patriarchal oppressive institution which should be avoided by all, gay and non-gay alike, ${ }^{11}$ others yet see it as an assimilationist threat to gay and lesbian lifestyles and to be avoided for that reason. ${ }^{12} \mathrm{I}$ want, in this article, to explain why I take the last of these approaches. I want to put forward the argument that, if marriage does retain relevance in the modern world, it does so only in the context of opposite-sex relationships. I should emphasise, however, that it is certainly no part of my argument that same-sex couples should be denied the rights, or be exempted from the liabilities, that the law grants to opposite-sex domestic partnerships, however few or many these legal consequences are in any particular jurisdiction. Any legal system that denies equality to different relationships based purely on the sexual orientation of the parties (and that includes most of them) is an iniquitous legal system. The point is that arguing for same-sex marriage is not, in my view, the best way to achieve equality.

\section{The Definition of Marriage}

Non-gay opponents to same-sex marriage often argue that the very concept is a contradiction in terms: marriage is, by definition, an opposite-sex relationship. A moment's thought, however, will show how unsatisfactory this assertion is. Marriage, as an institution, is not a natural phenomenon but is rather a legal structure, and, as such, it is one that is defined artificially by the law. So the law has the choice of how to define marriage and how to limit access to it. Every society defines marriage in a way that makes sense for itself and for its own (economic) needs and different societies define it differently. Indeed, they change their definitions as time goes by, the better to reflect contemporaneous social values. For example, some countries define it as a life-long relationship, escape from which is simply not possible,${ }^{13}$ others accept the idea of divorce. ${ }^{14}$ Some countries define marriage as a relationship between no more than two persons; others define it to include polygamous relationships; others continue to accept child-marriage. Some jurisdictions refused to recognise interracial marriage. ${ }^{15}$ The point is that there is no one, universally accepted, natural definition of marriage. It is entirely circular to say that marriage by definition is heterosexual because that is how marriage is defined.

Opponents of gay and lesbian equality often argue that marriage needs to be defended from same-sex attack because, as an institution, it is the basic building block of a settled and stable society. ${ }^{16}$ I have never really understood how this can be used as an argument against same-sex marriage. If social stability is a good thing, 
which it is, and if marriage does serve a stabilising function, which it does (although, in truth, it is the fact that exit from marriage is far harder than entry into it, that is the stabilising factor), then more, not fewer, people should be encouraged into the 'ties that bind'. Opponents of gay equality really want to encourage gay people into opposite-sex marriage because that is the only marriage they recognise, ${ }^{17}$ which is merely the 'definition' point again. A slightly more sophisticated argument (although in fact this too resolves itself into a definition argument) is that once you remove the requirement for heterosexuality, there is no justification for maintaining the other limitations on entry to marriage. Marriage might, therefore, evolve to include any relationship, however unstable, such as polygamous, short-term and incestuous relationships, so leading to a breakdown in social stability. ${ }^{18}$ However, this argument is based on a false premise. Removing one limitation to marriage, the requirement that it be between an opposite-sex couple, does not mean that we have to remove all limitations. What it does, of course, mean is that it is legitimate to question every limitation in order to ensure that it continues to serve some justifiable purpose in today's society. But there is nothing unusual about that. The limitations that UK law had on a man marrying his deceased wife's mother were scrapped in 1986. ${ }^{19}$ The limitations on interracial marriage were held to be no longer sustainable in the US in Loving $v$ Virginia. ${ }^{20}$ All limitations should, in other words, be kept under constant review and the removal of one limitation does not in itself justify removing another. Today it is perfectly rational to say that the exclusion of incestuous and polygamous relationships continues to serve important social functions; while no purpose is served by excluding same-sex couples from marriage other than, self-referentially, the maintenance of the current definition.

\section{So, What Is My Problem with Same-Sex Marriage?}

None of the above amounts to an argument against same-sex marriage. It simply states that same-sex marriage does not, in itself, challenge or attack marriage, as currently understood. My problem is not that I think marriage ought to be attacked (although I do), but that using marriage as the route to gay and lesbian equality is misconceived. It simply shifts the goalposts for relationships that are currently outside the law's ken. We can see the operation of this phenomenon in many jurisdictions' attempts to recognise same-sex relationships by founding upon their similarities with opposite-sex relationships. This is exemplified in England by the Fitzpatrick case ${ }^{21}$ and in Scotland by the first ad hoc statutory recognition of same-sex relationships. ${ }^{22}$ Similarly in Canada, with its much more comprehensive recognition, ${ }^{23}$ same-sex couples are recognised if they are in a relationship equivalent in all respects (except sexual orientation) to that of the opposite-sex couple who are 'living together as husband and wife'. By this means, paradoxically, the married relationship becomes the standard against which all other relationships are judged. The only way a same-sex couple can access statutory benefits ${ }^{24}$ is, therefore, to emulate as closely as possible the opposite-sex couple. The difficulty I have with this is that it requires the denial of some very real differences between same-sex and opposite-sex couples, and by requiring emulation, it denies equal respect to those couples who will not or cannot model their relationship on the heterosexist norm. Equality is granted, but only on heterosexual terms. ${ }^{25}$ Real equality, on the other hand, would come about by the law recognising the legitimacy of a variety of forms of domestic relationship, including those that have different perceptions of commitment and fidelity from how these notions are perceived in marriage. ${ }^{26}$

I will give two examples where the social and emotional structures of same-sex relationships often or usually do not follow those of opposite-sex relationships, although within these two examples one might well find all life contained - property and sex.

Property first. There is little doubt that marriage historically was first and foremost a property relationship, at least in legal terms. For most legal systems in the western world, the most significant practical effect of marriage at common law was that the woman's property was automatically transferred into the ownership of her husband. Furthermore, in many legal systems she herself fell under his guardianship or otherwise had her own legal personality subsumed into his. ${ }^{27}$ Marriage, in other words, was a powerful means whereby property (and with property, power) was concentrated in the male domain, and it was therefore the most significant means by which the inequality of the sexes was both institutionalised and perpetuated. Of course, past iniquities do not in themselves justify denying the worth of marriage today - rather the reverse, for marriage has proved itself able to develop and change and to respond to altering social needs. Today no 
western legal system maintains these original property effects of marriage ${ }^{28}$ However, the most significant consequence of marriage, as a legal institution, remains proprietorial. During marriage, under most legal systems, the income of both spouses can be accessed by the other, whether there is a community of property system or a postponed system. Both systems allow property or maintenance claims to be made at the end of the marriage, whether on death or divorce. ${ }^{29}$ These rules are designed, if somewhat clumsily, to harmonise the wealth of both parties in relationships which, by and large, are between individuals who in terms of wealth creation, tend to be unequal. In other words, the major legal purpose of marriage today is to respond to the social, indeed systemic, inequality between the sexes. As such, it is uniquely appropriate for opposite-sex couples, in the sense that it serves a social function for them which is misconceived for same-sex couples who do not, by definition, reveal a systemic inequality. ${ }^{30}$ Research has long shown that same-sex couples: (1) tend to be economically closer to each other, in terms of both wealth and earning power than opposite-sex couples; and (2) tend to avoid the economic inter-dependency on each other that so often characterises opposite-sex couples. ${ }^{31}$ There are fewer joint bank accounts, in other words. Yet when judges seeking to benefit same-sex couples look for 'commitment' between the couple, this social phenomenon amongst opposite-sex couples is seen as one of the most potent indicators with same-sex couples also. ${ }^{32}$ It may be appropriate for one, but it is far less appropriate for the other.

The same can be said for sex. In opposite-sex relationships an extremely high premium is paid in most societies to sexual fidelity. The marriage laws of most legal systems are full of concepts designed to emphasise the importance of keeping sex within marriage: concepts such as adultery, child-illegitimacy, consummation, incest and impotency. And the reason is not hard to find. For the single most important difference between heterosexual activity and homosexual activity is that the former has the unique potential, and the latter has absolutely no potential, to create new human life. ${ }^{33}$ Child creation is of the utmost importance to society. But it should be remembered that these rules were not designed to ensure that children have a stable family upbringing - that is a very late twentieth century notion. More important was the need for safe and secure property devolution. A man needs to know that the children who inherit his property are actually his children. A child needs to know that his or her father is not spreading his seed, and the child's inheritance, abroad. The very terminology of the law tells us this quite clearly if we care to look: adultery is the adulteration of the male blood line (so gay sex and oral sex never were - and cannot be - adultery). 'Illegitimacy' referred not to the child, since that would be grammatically inept, but rather to the child's claim to inheritance. In other words, heterosexual activity outwith the family relationship is economically very risky and property claims from outwith the family disrupt both the family and, thereby, society itself. Child creation therefore needs to be controlled for the stability of society. This is the reason why sexual fidelity is so important for heterosexuals - because their sort of sex, as both common experience and literary tradition show, can seriously disrupt family finances and lines of succession. And this explains why society, as a whole, sees heterosexual activity outwith marriage as so threatening and disruptive, and why the law sees it as destructive of the marital relationship. It is not the mean-spirited fear that one's partner is getting a modicum of physical pleasure outwith the relationship, for otherwise masturbation would be as much a ground for divorce as adultery, but the fear that one's partner may be creating children outwith the family.

None of these fears applies to same-sex relationships where, when there are children, both parties will nearly always be fully aware of where they came from - not through sex between the parties but often through hardfought and traumatic legal and medical battles. This, I think, is the real reason why sexual fidelity plays a far less central role in same-sex than in opposite-sex relationships. It is not that gay men and lesbians are naturally more promiscuous than non-gay people, nor even that men are naturally more promiscuous than women. It is that gay sex has, in practical terms, far fewer social consequences. It is therefore far lower down in participants' scale of values than non-gay sex, which might involve not only physical pleasure but economic costs, which is, of course, high on anyone's scale of values. The end result of this is that fidelity for gay men and lesbians tends to be understood in a rather different way. It is more emotional and less physical in meaning than it is for non-gay people: but it is no less important for all that.

\section{Conclusion}

So where is all this going? The real objection, in my view, to same-sex marriage is that if marriage does expand to include same-sex couples, it will not develop to reflect the needs and aspirations of same-sex 
couples when these differ from opposite-sex couples. Sex discrimination law has long recognised that equality is not necessarily achieved by treating different people identically. So too, relationship equality is unlikely to be achieved by treating different types of relationship identically, for that runs the risk of imposing inappropriate rules on some relationships. A good example of this is provided by the Vermont legislation permitting same-sex civil unions with almost all the same legal consequences as marriage. ${ }^{34}$ In order to achieve what was perceived as equality, all the rules of marriage, including those for entry into the institution, were imposed on civil unions. This means that the rules concerning the forbidden degrees of relationship apply to same-sex civil unions, ${ }^{35}$ notwithstanding that one of the primary purposes of barring incestuous marriages, although admittedly not the only one, is to avoid congenital abnormalities. This consideration is entirely irrelevant for same-sex couples. Such an example shows that with marriage would inevitably come all the (hetero)sexual baggage of consummation, incest, impotency and adultery. It would involve all the property baggage of loss of control of personal finances and all the inhibiting baggage of requiring the state's permission to escape from the relationship. The social advantage of status that marriage would bring is not, in my view, sufficient compensation.

But it may be argued if I, as an individual, am unwilling to subject myself to the heterosexual baggage associated with marriage then I am free to avoid the institution. I ought not, however, deny the opportunity to those who are willing so to subject themselves, gay and non-gay alike. But the point is that no such opportunity exists at the moment for same-sex couples and so the question must be posed: how ought the law change to accommodate the legitimate claims and expectations of such couples? There is a choice of solutions, only one of which is the opening of marriage. In my view the preferable solution for those seeking equal respect from the law for same-sex relationships is one which avoids the dangers of assimilation and inappropriate application posed by marriage.

\section{The ideal solution}

Sir Henry Maine, in the middle of the nineteenth century, identified, in his Ancient Law ${ }^{36}$ that the transition from ancient to modern law was essentially characterised by a movement from status to contract. The law of domestic relations has not yet made that transition. Marriage remains a status, although as such, it has long since outlived its usefulness. The time has come to move on to a more sophisticated conception of how the law can operate fairly for all citizens. The solution is to break marriage, as a legal concept, down into its constituent legal parts, with rights and liabilities being allocated, not according to marital status, but according to need, fairness and appropriateness in the individual case. ${ }^{37}$ Succession rights should no longer be allocated according to status, for that gives rights, irrespective of the realities of the relationship. Domestic violence remedies (surely self-evidently?) should be available whenever there is domestic violence, rather than only when the applicant fits in to an approved domestic status. ${ }^{38}$ Obligations of maintenance and property adjustment at the end of the relationship should depend on individualised factors, such as dependency, unjustified enrichment and voluntary assumption of mutual financial responsibility, rather than on the blunt instrument of status. This solution, in its fundaments, would require the termination of marriage as an institution with inherent legal consequences. This would leave it, rather like baptism, as a sacrament open to all of those who, for religious reasons, wish to have an aspect of their private life blessed by the religious organisation to whose teachings they adhere, but which has no legal consequence whatsoever. It is unlikely that the 'abolition' of marriage, as this solution would inevitably be characterised, would fall foul of Article 12 of the European Convention for the Protection of Human Rights and Fundamental Freedoms 1950. After all, that provision, unlike, say, Article 6 of the German Constitution, does not guarantee any special legal protection to marriage in the form of preferential legal treatment. It is, however, even more unlikely that any mainstream political party in the UK would give support to this solution. So instead of the ideal, we must, as is so often the case, be content with the practicable.

\section{The practicable solution}

As a minimum, those legal systems subject to the European Convention must comply with the requirements of Articles 8 and 14. Because discrimination in the respect given to private and family life on the basis of sexual orientation is 'intolerable' ${ }^{39}$ they must extend those legal consequences of unmarried cohabitation 
which already exist to same-sex cohabiting couples. In the UK, where the consequences are so few, this will not involve any great radical change. Other jurisdictions, where the consequences are greater, will end up with significantly enhanced recognition of same-sex relationships. Interestingly, it is France, a country which has for long given extensive legal consequences to cohabitation and now recognises these consequences as being almost the same as for marriage, which has opened these consequences to same-sex couples. ${ }^{40}$ In doing so, that country points the way to a practical solution more palatable than opening up marriage to or creating a new, analogous, institution for same-sex couples. ${ }^{41}$ Cohabitants' rights (and liabilities) are gradually being increased in the UK, and the consequences of marriage itself are gradually being reduced. Eventual coalescence, on the French model, is likely to happen later than the inevitable extension of cohabitants' rights (and liabilities) to same-sex couples. For that reason, the efforts of gay and lesbian activists would be better spent campaigning for that end result rather than for marriage or a marriage-like institution which will attract virulent opposition. ${ }^{42}$ Not only would that make the goal of equality more likely of achievement, but it would avoid the seductive dangers of false equality.

1 Not all of which, of course, have yet been won in all jurisdictions.

2 See Dudgeon v UK (1981) 4 EHRR 149; Norris v Ireland (1988) 13 EHRR 186; Modinos v Cyprus (1993) 16 EHRR 485.

$3 \quad$ Sutherland v UK (1998) EHRLR 117.

$4 \quad$ Salgueiro da Silva Mouta v Portugal (Case No 33290/96) 21 December 1999.

$5 \quad$ Smith and Grady v UK (2000) 29 EHRLR 493; Lustig-Prean and Beckett v UK (2000) 29 EHRR 548.

6 Disputes concerning the legal recognition of relationships have arisen in a number of jurisdictions. See Fitzpatrick v Sterling Housing Association [2000] 1 FLR 271 (England); Mv H (1999) 171 DLR (4th) 577 (Canada); National Coalition for Lesbian and Gay Equality $v$ Minister for Home H Home Affairs (1999) (3) BCLR 280 (South Africa); Baker v Vermont 744 A2d 864 (1999). For a discussion of these cases see K. McK Norrie, 'Constitutional Challenges to Sexual Orientation Discrimination' (2000) 49 ICLQ 755.

7 See M. P. Broberg, 'The registered partnership for same-sex couples in Denmark' [1996] CFLQ 149.

8 See I. Lund-Andersen, 'Cohabitation and Registered Partnerships in Scandinavia', in J. Eekelaar and T. Nhlapo (eds), The Changing Family: International perspectives on the family and family law (Hart Publishing, 1998); W. Schrama, 'Registered Partnerships in the Netherlands' (1999) 13 Int J Law Pol \& Fam 315.

9 An unofficial translation of the Bill accepted by the Dutch lower house of parliament in September 2000 can be found at http://ruljis.leiden.nl/user.cwaaldij/NHR/transl-marr.html

10 See D. Chambers, 'What If? The Legal Consequences of Marriage and the Legal Needs of Lesbian and Gay Male Couples' (1996) 95 Mich LR 447.

11 See, for example, N. Polikoff, 'We Will Get What We Ask For: Why Legalising Gay and Lesbian Marriage Will Not Dismantle the Legal Structure of Gender in Every Marriage' (1993) 79 Virg LR 1535.

12 The marriage debate is argued more extensively in the US than elsewhere, possibly because the institution of marriage provides the means whereby individuals access many private employmentrelated benefits, like pensions and health care, that in other countries are provided by the state. Extensive contributions to this debate are to be found in A. Sullivan (ed), Same-Sex Marriage: Pro and Con (Vintage, 1997) and R. Baird and S. Rosenbaum (eds), Same-Sex Marriage: The Moral and Legal Debate (Prometheus Books, 1997).

13 Until recently the Constitution of the Republic of Ireland prohibited courts in that jurisdiction from granting divorce. 
In Scotland divorce has been a judicial remedy since the Reformation (originally only on the ground of adultery and since 1573 on the ground of desertion also: see APS 1573, c 1). In England it has been available to the courts only since the Matrimonial Causes Act 1857.

This was the case in some states in the US until the Supreme Court decision of Loving v Virginia 388 US 1 (1967).

See, for example, 'Defending Marriage' in A. Sullivan (ed), op cit, n 12, at pp 204-209 and L. Wardle, 'Same-Sex Marriage and the Limits of Legal Pluralism' in J. Eekelaar and T. Nhlapo, op cit, $\mathrm{n} 8$.

An aspect of this argument was put forward by the state in the South African case of National Coalition for Gay and Lesbian Equality (1999) 3 BCLR 280, when they suggested that gay people were not discriminated against because they were free to marry persons of the opposite sex. The Constitutional Court of South Africa was contemptuous in its dismissal of this departure from reality.

A. Sullivan (ed), op cit, n 12, at pp 273-294.

Marriage (Prohibited Degrees of Relationship) Act 1986.

388 US 1 (1967).

Fitzpatrick v Sterling Housing Association [2000] 1 FLR 271.

See s 87(2) of the Adults with Incapacities (Scotland) Act 2000 (asp 4) which includes members of same-sex couples within the meaning of 'nearest relative' for the purposes of that Act.

See, as a representative example, the Definition of Spouse Amendment Act 1999 (British Columbia).

In the UK there are, in fact, few statutory rights and liabilities attaching to opposite-sex cohabiting couples, but there are some. In such cases, by and large, the exclusion of same-sex couples serves no rational purpose. Why, for example, should a heterosexual survivor of a cohabiting couple receive damages under the Fatal Accidents Act 1976 or the Damages (Scotland) Act 1976 when a homosexual survivor in identical circumstances would receive nothing? Why should an opposite-sex cohabiting couple suffer aggregation of income for the purposes of calculating entitlement to meanstested benefits (and legal aid) when a same-sex couple in identical circumstances are exempt from that economic disadvantage?

In J. Millbank's words, 'In legal discourse, all roads lead to a heteronuclear Rome': para 14 in 'Which Then Would be the "Husband" and Which the "Wife?": Some Introductory Thoughts on Contesting the "Family" in Court' (1996) 3(3) Murdoch Electronic Journal of Law, at www.murdoch.edu.au/elaw/

See S. Boyd, 'Expanding the "Family" in Family Law' (1994) 7 Canadian Journal of Women and the Law 545.

See the sixteenth century Scottish text William Hay's Lectures on Marriage, translated from the original Latin by J. C. Barry, Stair Society (1967) 24. This work is representative of the European tradition in marriage, based very firmly upon the Canon law.

Although customary law in, for example, South Africa, does. For a general discussion, see C. Himonga and C. Bosch, 'The Application of African Customary Law Under the Constitution of South Africa' (2000) 117 SALJ 306.

29 See, as representative examples, the Matrimonial Causes Act 1973 (England) and the Family Law (Scotland) Act 1985 (Scotland).

This, in essence, was the argument used by Gonthier J in his dissent in $M v H$ (1999) 171 DLR (4th) 577. However, in that case the point was subverted since the legislation at issue, being genderneutral, allowed claims for financial support based not on systemic inequality but on actual need and, as such, it was illogical to deny claims by members of same-sex couples who had actual need, while at the same time not suffering systemic inequality. The same criticism can, of course, be made in relation to the point being made here. 
G. Dunne, 'Balancing Acts: Lesbian Experiences of Work and Family Life', Report to the ESRC (1998); G. Dunne, 'A Passion for "Sameness"? Sexuality and Gender Accountability', in E. Silva and C. Smart (eds), The New Family? (Sage Publications, 1999), at pp 66-82.

This can be seen in the judgments in each of the cases listed at $n 6$ (above).

Even methods of assisted reproduction require male and female gametes, which cannot be obtained solely from a same-sex couple. The nearest example one can imagine of a same-sex couple both contributing to child creation is when one woman provides the ovum and her lesbian partner provides the womb, but even here (human cloning remaining in the realms of speculation) a male is required to provide sperm. Of course, I am talking here only of child creation; child rearing is quite different and may well be quite common amongst same-sex couples. An Act Relating to Civil Unions, No 91 of 2000, effective from 1 July 2000.

\section{Everyman's Library Edition, 1972, at p 100.}

This suggestion was made some time ago as a means of dealing with the conflict of laws problems associated with marriage - see W. Reese, 'Marriage in American Conflict of Laws' (1977) 26 ICLQ 952 - but it has more general merit. femedies contained in the Family Law Act 1996 are, it has to be admitted, consistent with this suggestion. In Scotland, disgracefully, the remedies for domestic violence contained in the Matrimonial Homes (Family Protection) (Scotland) Act 1981 can be accessed only by 'spouses' or 'cohabiting couples', both phrases being defined in exclusively heterosexual terms. See further, K. Norrie, 'We are Family (Sometimes): Legal Recognition of Same-Sex Relationships After Fitzpatrick' (2000) 4 Edin L R 256.

Da Silva Mouta v Portugal 21 December 1999, ECHR.

See A. Barlow and R. Probert, 'Addressing the Legal Status of Cohabitation in Britain and France: Plus ca Change ...?' (1999) Web J of Current Legal Issues, http://webjcli.ncl.ac.uk/1999/issue3/ barlow3.html; R. Probert and A. Barlow, 'Displacing marriage - diversification and harmonisation within Europe' [2000] CFLQ 153.

1 But see E. Steiner 'The spirit of the new French registered partnership law - promoting autonomy and pluralism or weakening marriage?' [2000] CFLQ 1, for a contrary view.

42 The 'Keep the Clause' campaign in Scotland in early 2000, set up to oppose the Scottish Parliament's plans to repeal the statutory prohibition on promoting the acceptability of same-sex relationships (Local Government Act 1986, s 2A), although ultimately unsuccessful, acts as a stark warning which requires, tactically, to be heeded. 